\title{
The Genetic Profile of Thrombophilia in Reproductive Disorders
}

\author{
GEORGETA CAMELIA COZARU ${ }^{1,2 *}$, MARIANA ASCHIE ${ }^{1,2}$, ANCA MITROI ${ }^{1,2}$, COSTEL BRINZAN ${ }^{1,2}$, ANCA CHISOI ${ }^{1,2}$ \\ ${ }^{1}$ CEDMOG, Ovidius University of Constanta, 145 Tomis Blvd., 900591, Constanta, Romania \\ 2Pathology Department, Emergency County Clinical Hospital of Constanta, 145 Tomis Blvd., 900591, Constanta, Romania
}

\begin{abstract}
Some cases of reproductive disorders have a thrombotic etiology. Considering the importance of establishing the cause of miscarriage, we investigated the incidence and associated risks of the most common thrombophilic genes polymorphism - FV G1691A, FV H1299A, Prothrombin G20210A, PAl-1, Factor XIII V34L, MTHFR C677T, MTHFR A1298C and EPCR genes, in women with reproductive disorders. In our research we included 139 women with reproductive disorders and risk for hereditary trombophilia and 139 healthy females without any personal or family history of vein thrombosis or recurrent pregnancy loss. For detection of thrombophilic genes polymorphism we used CVD StripAssay (ViennaLab, Austria) and the tests' protocols were followed as described by the manufacturer. Our results showed that the concomitant presence of MTHFR A1298C and Factor XIII V34L gene polymorphism had a significantassociation for recurrent pregnancy loss, while FV H1299A (R2) and MTHFR A1298C gene polymorphisms were correlated with subfertility. We therefore consider that these patients should be recognized as high risk for poor pregnancy outcomes and monitored with specialized follow-up.
\end{abstract}

Keywords: Inherited thrombophilia genes, reproductive disorders, recurrent pregnancy loss

Reproductive disorders have heterogeneous etiopathogenesis, including genetic, infective, anatomical, endocrine, and immune factors. To date, there has been no conclusive evidence in the literature to suggest an association of inherited thrombophilia and unexplained infertility [1]. Thrombophilia is an acquired or most commonly inherited condition that increases blood coagulation, leading to clot formation that may have important consequences on pregnancy [2]. Although it appears that the results of the published studies are conflicting, most reviews suggest an association of inherited thrombophilia with complications such as spontaneous loss of the fetus, preeclampsia, intrauterine growth restriction, placental abruption, and stillbirth, at different stages of the pregnancy [3]. Interest in genetic basis of thrombophilia was accelerated with discovery of factor V Leiden (FV) polymorphism G1691A, which is most common genetic risk factor [4]. Prothrombin G20210A, another common cause of hereditary thrombophilia, is also a risk factor for venous thrombosis (VT) [5]. Two common polymorphisms in methylene tetrahydrofolate reductase (MTHFR) gene including C677T and A1298C, lead to decreased enzyme activity and therefore elevation of homocysteine level. Several studies have shown that these two polymorphisms might be associated with VT due to hyperhomocysteinemia [6-9]. Factor XIII is a coagulation factor acting for stabilizing fibrin clot. It is represented by a human protein, encoded by the F13Al gene, named coagulation factor XIII. Defects in its gene can result in a lifelong bleeding tendency, defective wound healing, and habitual abortion, when associated to PAI-1 polymorphisms $[10,11]$. PAl-1 gene's promoter region contains at least two alleles producing either a $4 G$ or $5 G$ base-pair region. Normal $5 \mathrm{G}$ allele permits binding of transcription factor inhibitors that suppress gene transcription, while $4 \mathrm{G}$ allele is too small to bind these gene repressors. Individuals homozygous for $4 \mathrm{G} / 4 \mathrm{G}$ allele have a three to five fold higher level of circulating PAl-1 compared with those bearing the $5 \mathrm{G} / 5 \mathrm{G}$ or $5 \mathrm{G} / 4 \mathrm{G}$ alleles. Homozygosis for $4 G / 4 G$ allele is relatively common and causes a modestly increased risk of thromboembolism, fetal loss, IUGR, preeclampsia and preterm delivery [12].
Other coagulation pathways, involving endothelial protein $C$ receptor (EPCR) may modify risk of thrombosis in connection with above genotypes. EPCR enhances rate of protein $\mathrm{C}$ activation, thus contributing to regulation of thrombin formation by protein $C$ anti-coagulant pathway [13]. Rare allele of 4600A/G (haplotype A3) is associated with increased plasma levels of soluble EPCR (SEPCR), however, its association with risk of thrombosis is controversial [14-16].

In view of these data and prominent role of thrombophilia in miscarriages, we examined frequencies of thrombophilic polymorphisms FV G1691A (Leiden), FV H1299R (R2), Prothrombin G20210A, MTHFR C677T, MTHFR A1298C, Factor XIII V34L, PAI-1 4G/5G, EPCR A4600G, EPCR G4678C and we sought to find an association between these polymorphisms and reproductive disorders without a known cause.

\section{Experimental part}

\section{Patients and data collection}

Study was conducted at Centre for Research and Development of Morphological and Genetic Studies of Malignant Pathology (CEDMOG), Ovidius University of Constanta in collaboration with Pathology Department of the Emergency County Clinical Hospital of Constanta. The research was done on 139 women with reproductive disorders (subfertility, recurrent miscarriage, threatened abortion with adverse pregnancy outcomes), representing the study group and other 139 healthy females without any personal or family history of venous thrombosis or recurrent pregnancy loss, meaning control group. In all patients were used observational data sheets: medical history, physical examination, laboratory, imaging (abdominal ultrasound) and pathological examination. We excluded the cases with known cause of pregnancy loss or subfertility. Demographic characteristics (age) and known risk factors for thromboembolic disease were collected for all participants of study. Mean age was 34.00 \pm 6.00 years for study group. All study cases and controls were fully informed about study protocol by main researcher and have consented to participate in study by signing a written consent. 
Methods

DNA was isolated from EDTA anticoagulant whole blood and analyzed with CVD StripAssay ${ }^{\circledR} T$ kits (ViennaLab Diagnostics $\mathrm{GmbH}$, Austria). Purity/concentration of DNA solutions were assessed by measuring optical density at 260/280 nm using a NanoDrop One ${ }^{\mathrm{TM}}$ Spectrophotometer (Thermo Scientific ${ }^{T M}$ ) and Qubit $\circledast 3.0$ (Life Technologies). Procedure of DNA analysis included three steps: DNA isolation, PCR amplification using biotinylated primers and hybridization of amplification products to a test strip containing allele-specific oligonucleotide probes immobilized as an array of parallel lines. Bound biotinylated sequences were detected using streptavidin-alkaline phosphatase and color substrates. The assay covered 9 polymorphisms: FV G1691A (Leiden), FV H1299R (R2), Prothrombin G20210A, MTHFR C677T, MTHFR A1298C, Factor XIII V34L, PAI-1 4G/5G, EPCR A4600G, EPCR $\mathrm{G} 4678 \mathrm{C}$. The reaction included $50-100 \mathrm{ng}$ of the genomic DNA in $25 \mu \mathrm{L}$ PCR reaction mix. The initial denaturation step was at $94^{\circ} \mathrm{C}$ for $2 \mathrm{~min}$, followed by 35 cycles of $94^{\circ} \mathrm{C}$ for $15 \mathrm{~s}, 58^{\circ} \mathrm{C}$ for $30 \mathrm{~s}$, and $72^{\circ} \mathrm{C}$ for $30 \mathrm{~s}$ ending with a final extension for $3 \mathrm{~min}$ at $72^{\circ} \mathrm{C}$. The PCR products were electrophoresed on $2 \%$ agarose gel stained with ethidium bromide. For each polymorphic position, one of three possible patterns may be obtained: normal, heterozygous, or homozygous mutant genotype.

\section{Statistical analysis}

Alternative genotype frequencies for mutated target gene markers in RPL women's from both groups were compared using Pearson's test and T-test. Statistical analysis was performed using SPSS version 20 (SPSS, USA). Values of $p<0.05$ were considered statistically significant and mutated allele frequencies were discussed in this study.

\section{Results and discussions}

Epidemiological characteristics of patients with reproductive disorders

Epidemiological characteristics of study group shown a $24.50 \%$ from them had a family history of thrombophilia. Subfertility was diagnosed at $34.50 \%$ of cases. Recurrent spontaneous abortions in first trimester of pregnancy (RPL1) were observed at $60.40 \%$ from patients and $15.80 \%$ of cases had recurrent spontaneous abortions in second trimester of pregnancy (RPL2). Also, $12.2 \%$ had complications during pregnancy. The patients with miscarriage had undergone 1- 6 abortions (mean: $2.2 \pm$ $1.0)$.
Frequency of thrombophilic gene polymorphisms in reproductive disorders

The prevalence of the genotypes and alleles frequencies is presented in Table 1. In this case-control study, the most common polymorphism in the group of women with reproductive disorders was PAI-1 gene $(56.1 \%$ with $4 \mathrm{G} /$ $\% 5 \mathrm{G}$ alleles and $28.1 \%$ with $4 \mathrm{G} / 4 \mathrm{G}$ alleles), while in the control group, the most common polymorphisms were MTHFR-A1298C, Factor XIII-V34L and PAI-1, heterozygous alleles, each with $17.3 \%$ frequency.

FV G1691A (Leiden) distribution polymorphism was higher at heterozygous genotypes study group than controls (7.90\% vs. $4.30 \%)$. Also, incidence of homozygous mutant genotypes was higher at study group $(4,30 \%)$ than control group of patients (0.75\%). Incidence of FV H1299A (R2) heterozygous genotype for study group of patients was $10.8 \%$ higher than $6.50 \%$ for control group. Homozygous mutant genotype was represented only at study group of patients (2.10\%). Prothrombin G20210A polymorphisms were present at heterozygous genotype on study group (5.80\%), on control group (5.00\%) and $2.10 \%$ from homozygous mutant genotype was observed at study group. $7.90 \%$ of study group of patients were homozygous for MTHFR C677T comparative with $2.10 \%$ observed at control group of patients and $42.40 \%$ (study group) vs. $9.40 \%$ (control group) were carriers.

Frequency of homozygote mutant genotype for MTHFRA1298C were $10 \%$ in study group vs. $2.10 \%$ in control group and presence of heterozygote alleles were observed at $54 \%$ for study group vs. $17.30 \%$ for control group. Study patients (37.40\%) were carriers for Factor XIII V34L and $6.50 \%$ were homozygous. This polymorphism was also found at $17.30 \%$ from healthy patients in heterozygous pattern and $4.30 \%$ from control patients were presented homozygous mutant genotypes.

As we mentioned, a significant association was found between PAI-1 4G/4G and occurrence of recurrent spontaneous abortions being represented by $28.10 \%$ from homozygote mutant genotype and $56.1 \%$ from heterozygote $4 \mathrm{G} / 5 \mathrm{G}$ alleles. Healthy patients with heterozygous pattern were represented by $17.30 \%$ and $5.70 \%$ from control patients presented homozygous mutant genotype.

Regarding EPCR A4600G/G4678C haplotypes observed for experimental group (Table 2), the most frequent were A1/A2 (36.70\%) and A1/A1 (25.90\%) haplotypes followed by A2/A2 (15.10\%), A3/A3 (11.50\%) and A2/A3 (10.80\%), comparative with haplotypes frequency recorded in control group for A2/A2 haplotypes (35.50\%), followed by A1/A2

Table 1

ALLELIC AND GENOTYPES FREQUENCIES OF THE THROMBOPHILIC GENES POLYMORPHISMS IN STUDY GROUP (P) AND CONTROL GROUP (C)

\begin{tabular}{|c|c|c|c|c|c|c|}
\hline \multirow[b]{2}{*}{ Thrombophilic genes } & \multicolumn{2}{|c|}{ wylde type } & \multicolumn{2}{|c|}{ heterozygous } & \multicolumn{2}{|c|}{ homozygous polymorphism } \\
\hline & (P) $(n=139)$ & $\begin{array}{c}(C) \\
(n=139\end{array}$ & $\begin{array}{c}(P) \\
(n=139)\end{array}$ & $\begin{array}{c}(C) \\
(n=139\end{array}$ & $\begin{array}{c}(P) \\
(n=139)\end{array}$ & $\begin{array}{c}(C) \\
(n=139\end{array}$ \\
\hline FV G1691A (Leiden) & $127(91.4 \%)$ & $127(91.4 \%)$ & $11(7.9 \%)$ & $6(4.3 \%)$ & $1(0.7 \%)$ & $6(4.3 \%)$ \\
\hline FV H1299A (R2) & $124(89.2 \%)$ & $127(91.4 \%)$ & $15(10.8 \%)$ & $9(6.5 \%)$ & 0 & $3(2.1 \%)$ \\
\hline Prothrombin G20210A & $132(95.0 \%)$ & $128(92.1 \%)$ & $7(5.0 \%)$ & $8(5.8 \%)$ & 0 & $3(2.1 \%)$ \\
\hline MTHFR C677T & $69(49.6 \%)$ & $123(88.5 \%)$ & $59(42.4 \%)$ & $13(9.4 \%)$ & $11(7.9 \%)$ & $3(2.1 \%)$ \\
\hline MTHFR A1298C & $50(36.0 \%)$ & $112(80.6 \%)$ & $75(54.0 \%)$ & $24(17.3 \%)$ & $14(10.0 \%)$ & $3(2.1 \%)$ \\
\hline F XIII V34L & $78(56.1 \%)$ & $109(78.4 \%)$ & $52(37.4 \%)$ & $24(17.3 \%)$ & $9(6.5 \%)$ & $6(4.3 \%)$ \\
\hline PAI-1 & $22(15.8 \%)$ & $107(77.0 \%)$ & $78(56.1 \%)$ & $24(17.3 \%)$ & $39(28.1 \%)$ & $8(5.7 \%)$ \\
\hline
\end{tabular}


Fig.1. Example of banding patterns on strips developed by reverse blotting with PCR amplicons

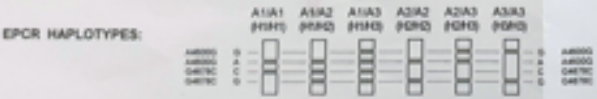

Table 2

EPCR HAPLOTYPES FREQUENCY IN STUDY GROUP (P) VERSUS CONTROLS (C)

\begin{tabular}{|c|c|c|}
\hline $\begin{array}{c}\text { Haplotypes } \\
E P C R \text { A4600G/G4678C }\end{array}$ & Study group (P) & Control group (C) \\
\hline A1/A1 & $36(25.9 \%)$ & $19(13.7 \%)$ \\
\hline Al/A2 & $51(36.7 \%)$ & $33(23.7 \%)$ \\
\hline A2/A2 & $21(15.1 \%)$ & $49(35.3 \%)$ \\
\hline $\mathbf{A 2} / \mathbf{A 3}$ & $15(10.8 \%)$ & $27(19.4 \%)$ \\
\hline $\mathbf{A} 3 / \mathbf{A 3}$ & $16(11.5 \%)$ & $11(7.9 \%)$ \\
\hline
\end{tabular}

haplotypes (23.70\%), A2/A3 (19.40\%), A1/A1 (13.70\%) and A3/A3 (7.90\%).

We found significant positive correlations between: cases with subfertility and FV H1299A (R2) gene polymorphisms $(r=.186, p=.028)$; cases with subfertility and MTHFR A1298C gene polymorphisms ( $r=.203$, $p$ $=.016$ ); and between repeated spontaneous abortions in the first trimester and F XIII V34L gene polymorphisms ( $r$ $=, 184, p=0.03$ ). We also noticed a significant negative correlation between cases with repeated spontaneous abortions in the first trimester and MTHFR A1298C gene polymorphisms $(r=-.264, p=0.001)$ (Table 3 ).

Other significant positive correlations were observed between patients with subfertility and presence of MTHFR A1298C gene polymorphisms $(r=.203, p<0.05)$ and also between repeated spontaneous abortions in the first trimester (RPL1) and F XIII V34L gene polymorphisms ( $r$ $=.84, p<0.05)$. Significant negative correlation were identified between patients with repeated spontaneous abortions in the first trimester (RPL1) and MTHFR A1298C gene polymorphisms $(r=-.264, p<0.01)$. Also was observed a statistically significant difference between $\mathrm{F}$ XIII V34L mutant gene $(6.47 \%$ vs. $4.32 \%, p<0.01)$ and MTHFR C67TT mutant gene $(7.91 \%$ vs. $1.16 \%, p<0.05)$ at patients with recurrent pregnancy loss (RPL) comparative with control patients.

Pregnancy is a prothrombotic state with multifactorial setting of underlying pathophysiologic changes leading to an increase of procoagulant factors, but reports' regarding association between inherited prothrombotic defects and

Table 3

CORRELATIONS BETWEEN THROMBOPHILIC GENE POLYMORPHISMS IN WOMEN WITH REPRODUCTIVE DISORDERS (P CALCULATION WAS PERFORMED FOR HOMOZYGOUS VS. HETEROZYGOUS)

\begin{tabular}{|c|c|c|c|c|c|c|c|c|c|c|c|c|c|c|c|}
\hline \multirow{2}{*}{\multicolumn{2}{|c|}{ Genotype }} & \multicolumn{2}{|c|}{$\begin{array}{l}\text { FV G1691A } \\
\text { (Leiden) }\end{array}$} & \multicolumn{2}{|c|}{$\begin{array}{l}\text { FV H1299A } \\
\text { (R2) }\end{array}$} & \multicolumn{2}{|c|}{$\begin{array}{l}\text { Prothrombin } \\
\text { G20210A }\end{array}$} & \multicolumn{2}{|c|}{$\begin{array}{l}\text { MTHFR } \\
\text { C677T }\end{array}$} & \multicolumn{2}{|c|}{$\begin{array}{l}\text { MTHFR } \\
\text { Al298C }\end{array}$} & \multicolumn{2}{|c|}{ F XIII V34L } & \multicolumn{2}{|l|}{ PAI-1 } \\
\hline & & $\mathrm{NA}$ & $\mathrm{AA}$ & $\mathrm{NA}$ & AA & NA & AA & NA & $\mathrm{AA}$ & NA & $\mathrm{AA}$ & $\mathrm{NA}$ & $\mathrm{AA}$ & $\mathrm{NA}$ & $\mathrm{AA}$ \\
\hline \multirow[t]{3}{*}{ SUBF" } & (\%) & 12.24 & 0 & 18.36 & 0 & 6.12 & 0 & 38.77 & 6.12 & 48.97 & 20.41 & 28.57 & 4.08 & 59.18 & 26.53 \\
\hline & $\begin{array}{l}\text { Pearson } \\
\text { Correlation }\end{array}$ & \multicolumn{2}{|l|}{.073} & \multicolumn{2}{|l|}{$.186^{\circ}$} & \multicolumn{2}{|l|}{.040} & \multicolumn{2}{|l|}{-.071} & \multicolumn{2}{|l|}{$.203^{*}$} & \multicolumn{2}{|l|}{-.152} & \multicolumn{2}{|l|}{.026} \\
\hline & $\begin{array}{l}\text { Sig. } \\
\text { tailed) }\end{array}$ & \multicolumn{2}{|l|}{.396} & \multicolumn{2}{|l|}{.028} & \multicolumn{2}{|l|}{.637} & \multicolumn{2}{|l|}{.407} & \multicolumn{2}{|l|}{.016} & \multicolumn{2}{|l|}{.074} & \multicolumn{2}{|l|}{.759} \\
\hline \multirow[t]{3}{*}{ RPLI } & (\%) & 4,76 & 1,19 & 7,14 & 0 & 4,76 & 0 & 42,85 & 9,52 & 55.95 & 2,38 & 42,85 & 8,33 & 52,38 & 29,76 \\
\hline & $\begin{array}{l}\text { Pearson } \\
\text { Correlation }\end{array}$ & \multicolumn{2}{|l|}{-.087} & \multicolumn{2}{|l|}{-.145} & \multicolumn{2}{|l|}{-.015} & \multicolumn{2}{|l|}{.071} & \multicolumn{2}{|c|}{$-.264^{* *}$} & \multicolumn{2}{|l|}{$.184^{*}$} & \multicolumn{2}{|l|}{-.006} \\
\hline & $\begin{array}{l}\text { Sig. } \\
\text { tailed) }\end{array}$ & \multicolumn{2}{|l|}{.310} & \multicolumn{2}{|l|}{.087} & \multicolumn{2}{|l|}{.856} & \multicolumn{2}{|l|}{.407} & .001 & & .030 & & .942 & \\
\hline RPL2 & (\%) & 4.54 & 0 & 4.54 & 0 & 9.09 & 0 & 31.81 & 4.54 & 63.63 & 4.54 & 22.72 & 13.63 & 68.18 & 18.18 \\
\hline & $\begin{array}{l}\text { Pearson } \\
\text { Correlation }\end{array}$ & -.066 & & -.087 & & .080 & & -.119 & & -.009 & & -.003 & & -.051 & \\
\hline & $\begin{array}{l}\text { Sig. } \\
\text { tailed) }\end{array}$ & .438 & & .306 & & .346 & & .163 & & .911 & & .976 & & .549 & \\
\hline APO & (\%) & 11.76 & 0 & 5.88 & 0 & 5.88 & 0 & 47.05 & 11.76 & 52.94 & 17.64 & 29.41 & 5.88 & 35.29 & 35.29 \\
\hline & $\begin{array}{l}\text { Pearson } \\
\text { Correlation }\end{array}$ & .29 & & -.059 & & .014 & & .073 & & .084 & & -.056 & & -.036 & \\
\hline & $\begin{array}{l}\text { Sig. } \\
\text { tailed) }\end{array}$ & .738 & & .489 & & .866 & & .396 & & .324 & & .515 & & .670 & \\
\hline
\end{tabular}

. Correlation is significant at the 0.05 level (2-tailed).

${ }^{* 8}$. Correlation is significant at the 0.01 level (2-tailed).

* Subfertility was defined as a delay of 1 year or more before a recognized conception was achieved.

Note: SUBF= Subfertility; RPL 1 = Miscarriage I trimester, RPL 2 = Miscarriage II trimester; APO=Threatened abortion with adverse pregnancy outcomes; NA = Heterozygous genotype; $\mathrm{AA}=$ Homozygous mutant genotype 
some obstetric complications (recurrent miscarriage or vascular gestational complications) are very controversial [17]. Reproduction disorders appears to increase in frequency when two or more concomitant thrombophilic defects are present, so it is important to determine frequencies and risks of most common mutant genes causing vein thrombosis or recurrent pregnancy loss [18].

Mostly, pregnant women are investigated for thrombophilia if they are diagnosed with: fetal growth delays, changes in uterine circulation with increased blood pressure in the uterine circulation at doppler ultrasound examination, increased blood pressure to extreme eclampsia - preeclampsia and pathology placenta dealt with the placenta aging. Frequently, women with thrombophilia have previously lost pregnancies. Fetal loss is a common and considerable problem during pregnancy. About $20 \%$ of women worldwide have at least one abortion and $5 \%$ have two or more spontaneous pregnancy losses [19]. The most common reason for adverse pregnancy outcome in the first trimester consists in fetal chromosomal abnormalities which are not compatible with survival. However, $30-40 \%$ of recurrent fetal losses remain unexplained after standard gynecological, hormonal and cytogenetic investigations [19]. Prime candidates forming molecular basis of fetal loss are various acquired or inherited hypercoagulation disorders promoting thrombosis, collectively termed 'thrombophilias' [20]. These conditions often associate infertility. Very often are women with primary infertility who have not found a cause, both in them and in the partner, and a thrombophilia screening reveals the presence of thrombophilic pathologies, often complex.

Thrombophilia may be anticipated by single or combined hereditary defects in encoding genes factor $V$, Prothrombin, and MTHFR. Interest in the genetic basis of thrombosis was accelerated with the discovery of the factor $V$ Leiden (FV) polymorphism G1691A, which is considered to be the most common genetic risk factor [4]. Based upon current knowledge, genetic testing for the FVL polymorphism and prothrombine G20210A variant is indicated for women with RPL or nonrecurrent late miscarriage, while determination of polymorphisms of the MTHFR gene is only indicated in cases with a high level of homocysteine [21]. In the present study Factor V G1691A (Leiden) polymorphism in patients suffering recurrent pregnancy loss (RPL1) was not significantly different from controls and did not reveal an association with RPL ( $p>0.05$, table 4), but we found significant positive correlations between cases with subfertility and FV H1299A (R2) gene polymorphisms $(r=.186, p=.028)$. Also Kobashi et al. [22], haven't found the FV Leiden polymorphism in Japanese women with RPL. According to the literature, most commonly thrombophilic genes polymorphism related to RPL are: Factor V G1691A (Leiden, 2-15\%) mutant genes, polymorphism in promoter region of prothrombin gene G20210A (2-3\%) and homozygosis of C677T polymorphism in methylene tetrahydrofolate reductase (MTHFR, 11\%). These polymorphisms are associated with a mild thrombotic risk in association with recurrent pregnancy loss [23]. Dragos Erdelean et al. (2018) [24] study showed that the MTHFR C67TT variant was found in heterozygosity in $56.4 \%$ of the patients, while $16.4 \%$ of the cases had the homozygote polymorphism genotype; 4G/ $5 \mathrm{G}$ genotype for PAl-1 gene was $76.4 \%$ and $4 \mathrm{G} / 4 \mathrm{G}$ was 21.8\%; while FVL polymorphism was present only in heterozygote state, $14.5 \%$ of the patients. Compared with the results of this study, conducted also on patients in Romania, observations were similar for MTHFR C67TT gene polymorphism frequency, butfor PAl-1 gene polymorphism, we have noted a lower frequency of heterozygous status (only $56.1 \%$ ) and a slightly higher $4 \mathrm{G} / 4 \mathrm{G}$ genotype (respectively $28.1 \%$ ). Concerning the $\mathrm{FVL}$ gene polymorphism, $7.9 \%$ of patients had heterozygous allelic variants, and $0.7 \%$ had homozygous polymorphisms.

We also noticed that patients with early recurrent abortions have more frequently presented polymorphisms of the PAl-1 gene, the MTHFR A1298C gene and the MTHFR C677T gene. Polymorphisms of the FVL and FV (R2) genes, as well as the G20210A prothrombin gene, were found in percentages similar to those in the literature and showing a non-significant association between patients and controls $[25,26]$. Our study, however, revealed a more frequent association of FXIII V34L gene polymorphisms in patients with reproductive disorders, especially those with early RPL compared to other studies. Deficiencies in normal coagulation proteins can also lead to a hypercoagulable state. Abnormalities in antithrombin are all associated with thrombophilia during pregnancy. Changes in these coagulation factors occur as a physiological manifestation of pregnancy [27]. The reported differences in the frequency of thrombophilic gene polymorphisms compared to other studies can be attributed to the methodological aspects, such as the inclusion of participants. The gestational age of pregnancy loss may also influence the strength of this association.

\section{Conclusions}

Our findings suggest that thrombophilic mutant genes may play a role in pathogenesis of reproductive disorders that should not be neglected, but we cannot appreciate the impact of these genetic polymorphisms on the occurrence of miscarriage. Knowing that reproductive disorders have several etiological factors and during pregnancy, changes in blood coagulation may play a role in the occurrence of miscarriage, we believe that in the case of a positive history of venous thrombosis or repeated spontaneous abortions / subfertility, it is indicate to determine the profile of the thrombophilic genes in order to establish a possible cause for the miscarriage and to conduct adequate monitoring of patients. By following, we recommend a routine screening for thrombophilic defects in women with previous pregnancy complications. However, the etiologic identification of genetic factors is important for genetic counselling.

Acknowledgments: The research was made possible following completion of the projectPOSCCE 2.21., ID 1844, SMIS 48750, CEDMOG.

\section{References}

1.CASADEI L., PUCA F., PRIVITERA L., ZAMARO V., EMIDI E.. Inherited thrombophilia in infertile women: implication in unexplained infertility. Fertil\&Steril. 94:755-7 (2010)

2.BRANCH D.W., SILVER R.M., BLACKWELL J.L., READING J .C., SCOTT J.R.. Outcome of treated pregnancies in women with antiphospholipid syndrome: um update of the Utah experience. Obstet Gynecol.; 80: 614-620 (1992)

3.SPYROS A.L., TSIKOURAS P., MANAV B., CSORBA R., VON TEMPELHOFF G.F., GALAZIOS G.. Inherited thrombophilia and reproductive disorders. J Turk Ger Gynecol Assoc.; 17(1): 45-50. doi: 10.5152/jtgga.2016.15212 (2016)

4.LIMDI N.A., BEASLEY T.M., ALLISON D.B., RIVERS C.A., ACTON R.T. Racial differences in the prevalence of Factor $V$ Leiden mutation among patients on chronic warfarin therapy. Blood Cells Mol Dis.; 37(2): 100-106 (2006)

5.SELIGSOHN U., LUBETSKY A. Genetic susceptibility to venous thrombosis. N Engl J Med.; 344 (16):1222-1231 (2001) 
6.JURCUT R., POP I., CORIU D. et al. Compound heterozygosity for the C677T and A1298C mutations of the MTHFR gene in a case of hyperhomocysteinemia with recurrent deep thrombosis at young age. Rom J Intern Med.; 46(3):255-9 (2008)

7.OZTUZCU S., ERGUN S., ULA ${ }^{a}$ LI M.et al. Evaluation of Factor $V$ G1691A, prothrombin G20210A, Factor XIII V34L, MTHFR A1298C, MTHFR C677T and PAI-1 4G/5G genotype frequencies of patients subjected to cardiovascular disease (CVD) panel in south-east region of Turkey. Mol Biol Rep.; 41(6):3671-3676 (2014)

8.POP T.R., VESA S.C., TRIFA A.P., CRISAN S., BUZOIANU A.D. PAI-1 4G/ $5 \mathrm{G}$ and MTHFR C677T polymorphisms increased the accuracy of two prediction scores for the risk of acute lower extremity deep vein thrombosis. Rom J Morphol Embryol.; 55(1):153 (2014)

9.SAPOSNIK B., LESTEVEN E., LOKAJ CZYK A., ESMON C.T., AIACH M., GANDRILLE S., Alternative mRNA is favored by the $A 3$ haplotype of the $\mathrm{EPCr}$ gene PrOCr and generates a novel soluble form of EPCr in plasma. Blood.; 111 (7):3442-3451 (2008)

10.BAGOLY Z., KONCZZ., HARSFALVI J ., MUSZBEK L. Factor XIII, clot structure, thrombosis. Thromb Res.; 129:382-387 (2012)

11.BATTINELLI E.M., MARSHALL A., CONNORS J .M., The Role of Thrombophilia in Pregnancy, Hindawi Publishing Corporation, Thrombosis, Volume 2013, Article ID 516420, 9 pages, http://dx.doi.org/ $10.1155 / 2013 / 516420,(2013)$

12.IWAKI T., TANAKA A., MIYAWAKI Y. et al. Life-threatening hemorrhage and prolonged wound healing are remarkable phenotypes manifested by complete plasminogen activator inhibitor-1 deficiency in humans. J. Thromb. Haemost. 9(6), 1200- 1206 (2011)

13.*** ESMON C.T. Protein C anticoagulant pathway. Arterioscler. Thromb. 12, 135-145(1992)

14.LIATSIKOS A.S., TSIKOURAS P., MANAV B., CSORBA R., G.F. von TEMPELHOFF, GALAZIOS G. Inherited thrombophilia and reproductive disorders. J Turk Ger Gynecol Assoc; 17: 45-50 (2016)

15.ROOSENDAAL F.R., DOGGEN C., ZIVELIN A., ARRUDA V., AIACH M. Geographic distribution of the $20210 \mathrm{G}$ to A prothrombin variant. Thromb Haemost.; 79:706-708 (1998)

16.UITTE DE WILLIGE S., VAN MARION V., ROSENDAAL F.R., VOS H.L., VISSER D.E., BERTINA R.M. Haplotypes of the EPCR gene, plasma SEPCR levels and the risk of deep venous thrombosis. J. Thromb. Haemost. 2, 1305-1310 (2004)
17.KOCHER O., CIROVIC C., MALYNN E., et all. Obstetric complications in patients with hereditary thrombophilia identified using the LCX microparticle enzyme immunoassay : a controlled study of 5,000 patients. Am J Clin Pathol.; 127(1):68-75 (2007)

18.BOGDANOVA N., MARKOFF A. Genetic Predispositions to Thrombophilia Associated with Recurrent Pregnancy Loss. J. Reproduktionsmed. Endokrinol.; 5 (2), 101-105 (2008)

19.BRANCH D.W., SILVER R.M., BLACKWELL J.L., Reading J C, Scott $J R$. Outcome of treated pregnancies in women with antiphospholipid syndrome: um update of the Utah experience. Obstet Gynecol 1992; 80: $614-20$

20.KUPFERMINC M.J ., ELDOR A., STEINMAN N., MANY A., BAR-AM A., JAFFA A., FAIT G., LESSING J.B. Increased frequency of genetic thrombophilia in women with complications of pregnancy. $\mathrm{N}$ Engl J Med; 340: 50- 2 (1999)

21.MARKOFF A., BOGDANOVA N., SAMAMA M.M.. Hereditary Thrombophilic Risk Factors for Recurrent Pregnancy Loss, Markoff et al., Hereditary Genetics, S:1 http://dx.doi.org/10.4172/2161-1041.S1-001 (2012)

22.KOBASHI G., KATO E.H., MORIKAWA M., et al. MTHFR C677T Polymorphism and factor $V$ leiden mutation are not associated with recurrent spontaneous abortion of unexplained etiology in Japanese women. Semin Thromb Hemost.; 31(3): 266-271 (2005)

23.BRENNER B., SARIG G., WEINER Z., et al. Thrombophilic polymorphisms are common in women with fetal loss without apparent cause. Thromb Haemost.; 82: 6-9 (1999)

24.ERDELEAN, D., FARCAS, S.S., POROCH, V., ANDREESCU, N.I., ERDELEAN, I., DOBRESCU, A.I., NUSSBAUM, L.A., HOGEA, L.M., NAVOLAN, D., TUTAC, P., PUIU M. Association Between Thrombophilia Gene Polymorphisms and Recurrent Pregnancy Loss., Rev. Chim. (Bucharest), 69, no. 11, 2018, p. 3122

25.DIZON-TOWNSON D., MILLER C., SIBAI B., et al. The relationship of the factor $\mathrm{V}$ Leiden mutation and pregnancy outcomes for mother and fetus. Obstet Gynecol.; 106:517-524 (2005)

26.YOUSEFIAN E., KARDI M.T., ALLAHVEISI A. Methylenetetrahydrofolate Reductase C677T and A1298C Polymorphism in Iranian Women with Idiopathic Recurrent Pregnancy Losses. Iran Red Crescent Med J.; 16 (7): e16763 (2014)

27.COZARU G.C., BUTNARIU L.I., GORDUZA E.V. Genetic counselling in reproductive disorders. Procedia-Social and Behavioral Sciences, 33, 213-217 (2012).

$\overline{\text { Manuscript received: } 22.10 .2019}$ 